\title{
Organ donation by patients with and without trauma in a Canadian province: a retrospective cohort analysis
}

\author{
Sara Lanteigne MBA, Mete Erdogan PhD, Alexandra Hetherington MSc, Adam Cameron BA, \\ Stephen D. Beed MD, Robert S. Green MD
}

\section{Abstract}

Background: People who experience trauma represent a large pool of potential organ donors. Our objective was to describe organ donation by patients with and without trauma in Nova Scotia.

\begin{abstract}
Methods: We performed a retrospective cohort study of all patients with trauma in the Nova Scotia Trauma Registry who were injured between Apr. 1, 2009, and Mar. 31, 2016, and died in hospital, as well as all potential organ donors captured in the Nova Scotia Legacy of Life Donor Registry over the same period. We compared characteristics of the 2 groups with respect to organ donation and identified reasons for nondonation.
\end{abstract}

Results: Overall, 940 patients were included in the analysis, of whom 689 (73.3\%) had experienced trauma. Patients with trauma accounted for $37.2 \%(48 / 129)$ of donors. A total of $274(39.8 \%)$ of the patients with trauma were identified as potential organ donors, and $48(7.0 \%)$ donated organs. Only $108(39.4 \%)$ of the 274 were referred to the Legacy of Life Program. The conversion rate (proportion of potential donors who went on to donate an organ) was $84.2 \%(48 / 57)$ among patients with trauma and $83.5 \%(81 / 97)$ among those without trauma. Donation after circulatory death occurred in 8 patients (17\%) with trauma and $13(16 \%)$ of those without trauma. Family refusal (28/60 [47\%]) and medical unsuitability (16/60 [27\%]) were the most common reasons for nondonation among patients with trauma.

Interpretation: In Nova Scotia, $40 \%$ of patients with trauma who died in hospital were potential organ donors, yet only $39 \%$ of these patients were referred for donation. More work is required to improve organ donation within the trauma population.

rgan transplantation is the best therapeutic option for patients with terminal organ failure; however, the availability of organs remains insufficient to meet demand. ${ }^{1-3}$ The organ donation and transplantation system in Canada is underperforming. ${ }^{2}$ Although 2559 organ transplantation procedures were performed in 2015 , 4631 patients remained on the wait list by year's end, and 262 died waiting for a transplant. ${ }^{2}$ Despite an increase in organ donation over the last decade, Canada's donation and transplantation rates per million remain well below those of other countries such as Spain, Croatia and the United States. ${ }^{2}$

People who experience trauma represent a large pool of potential organ donors, and many authors have suggested opportunities to improve organ donation rates among these patients. ${ }^{4-9}$ Given the discrepancy between demand and performance, it is critical to evaluate patients with trauma as potential donors. ${ }^{3,4,10}$ There is a trend toward lower rates of death from head trauma among Canadian donors and an increasing median age of deceased donors, attributable in part to advances in the prevention and care of brain injuries. ${ }^{11-13}$ It remains unclear whether identification of potential donors, consent and conver- sion rates (proportion of potential donors who go on to donate an organ) differ between patients with and without trauma. To aid physicians caring for patients with severe trauma to better recognize potential donors, our objectives were to compare donation rates between patients with trauma and those without trauma and to identify reasons for nondonation.

\section{Methods}

\section{Study design and population}

We conducted a retrospective cohort study using data from the Nova Scotia Trauma Registry and the Nova Scotia Legacy of Life Donor Registry. Nova Scotia Trauma Registry

Competing interests: None declared.

This article has been peer reviewed.

Correspondence to: Robert Green, greenrs@dal.ca

CMAJ Open 2018. DOI:10.9778/cmajo.20180026 
participants included all patients with trauma provincially as well as those referred from Newfoundland and Labrador, New Brunswick and Prince Edward Island who were injured between Apr. 1, 2009, and Mar. 31, 2016, and died in any Nova Scotia hospital. We also included all patients (with and without trauma) in the Legacy of Life Donor Registry over the same 7-year period. The start date for the study coincides with the beginning of data collection in the Legacy of Life Donor Registry. Data were linked to identify patients with trauma with records in both registries.

\section{Data sources}

The Nova Scotia Trauma Registry is a provincial populationbased registry under the Nova Scotia Department of Health and Wellness with data for all patients with an Injury Severity Score of 12 or higher and an appropriate International Classification of External Causes of Injury (ICECI) code. ${ }^{14}$ The registry also includes cases of penetrating trauma with an Injury Severity Score of 9 or higher, all trauma team activations regardless of Injury Severity Score, and cases of trauma resulting in death before arrival at the hospital or in the emergency department. Data are collected from all regional hospitals and tertiary care centres and from the Nova Scotia Medical Examiner Service. The registry has quality-control procedures in place to ensure accurate and complete data entry including computer checks (e.g., drop-down menus), visual checks (registry coordinator visually scans data before entry) and a reabstracting audit of $10 \%$ of cases annually.

The Legacy of Life Program was created in 2006 to raise awareness about the importance of organ and tissue donation. ${ }^{15}$ The program maintains the Legacy of Life Donor Registry, which contains data regarding potential donors at (or transferred to) the Queen Elizabeth II Health Sciences Centre, Halifax, as well as information regarding potential donors not referred to the program as determined via retrospective province-wide death audits. The Queen Elizabeth II Health Sciences Centre is the only Atlantic site performing organ donation (after neurologic or cardiocirculatory determination of death) and solid organ transplantation.

\section{Study definitions}

A potential donor in the Nova Scotia Trauma Registry was a patient with trauma who had an appropriate ICECI code (Appendix 1, available at www.cmajopen.ca/content/6/3/E300/ suppl/DC1) and who received mechanical ventilation before death in hospital. A potential donor in the Legacy of Life Donor Registry was a patient who met the following criteria after transfer and assessment at the Queen Elizabeth II Health Sciences Centre: 1) Glasgow Coma Scale score of 5T or less, or grave prognosism, 2) injured brain or nonrecoverable injury or illness, 3) endotracheal tube in place and ventilatordependent and 4) end-of-life discussion held with family and decision made to withdraw life-sustaining therapy. An eligible donor in the Legacy of Life Donor Registry was a patient referred to the Legacy of Life Program who was deemed medically suitable and whose family consented to proceed with donation. There were 2 types of eligible donors: those who donated after neurologic determination of death and those who donated after circulatory death. A missed referral was a patient who met all 4 criteria but was not referred to the program.

\section{Data collection}

Data collected from the Nova Scotia Trauma Registry included age, sex, injury date, injury location (within Halifax Regional Municipality v. outside), injury type (blunt, penetrating, burn, drowning/asphyxia), injury cause, ICECI code, mode of transport to final institution (land, air [included both helicopter and fixed-wing aircraft], combination land/air, private vehicle, walk-in), intermediate facilities, trauma team activation, scene Glasgow Coma Scale score, Injury Severity Score, Abbreviated Injury Score, length of stay (intensive care unit and total hospital stay), mechanical ventilation requirement, comorbidities, residential postal code and institution where death occurred.

From the Legacy of Life Donor Registry, we collected data on organ donors (potential, eligible, actual), organs procured (number, type), missed referrals and reasons for nondonation. We also collected information on whether the patient had indicated his or her intent to donate by signing the provincial Medical Services Insurance health card, and whether he or she intended to donate all organs or specific organs only. Any variables with missing values were noted in the results.

\section{Statistical analysis}

The sample size was dependent on the number of in-hospital deaths in the Nova Scotia Trauma Registry and records in the Legacy of Life Donor Registry during the study period. We characterized patients using descriptive statistics including means, standard deviations and proportions. Data on injury cause, ICECI codes, diagnoses and patient comorbidities were grouped into categories. We compared patient characteristics using parametric (Student $t$ test, $\chi^{2}$ analysis) and nonparametric (Mann-Whitney test, Fisher exact test) tests as appropriate. Based on recommendations from the Canadian Blood Services Deceased Donation Data Working Group, ${ }^{16}$ we calculated the organ donation rate (i.e., conversion rate) by dividing the number of actual donors (consented and at least 1 organ transplanted) by the number of eligible donors (approached for donation, excluding medically unsuitable or missed referrals). Eligible potential donors who later became medically unsuitable were excluded from the conversion rate. We calculated the consent rate as the number of potential donors with family consent obtained divided by the number of potential donors (or their families) approached for consent. We performed subgroup analysis of organ donation among patients who indicated their intent to donate by signing their health card. In keeping with the privacy policy of the Nova Scotia Department of Health and Wellness, any counts less than 5 are suppressed and are reported as $n<5$. All analysis was performed with SPSS version 24 (IBM Corp.).

\section{Ethics approval}

Study approval was obtained from the Nova Scotia Health Authority Research Ethics Board. 


\section{Results}

A total of 7140 patients were eligible, most of whom (6781 [95.0\%]) had experienced trauma (Figure 1). After we excluded patients who survived to hospital discharge, 940 patients remained for analysis: 581 with trauma in the Nova Scotia Trauma Registry, 251 without trauma in the Legacy of Life Donor Registry and 108 with trauma with records in both registries.
A total of $40.0 \%(274 / 689)$ of patients who died in hospital met the Nova Scotia Trauma Registry definition of a potential donor, yet only 39.4\% (108/274) of potential donors were referred to the Legacy of Life Program (Table 1). Potential donors not referred were older and less severely injured than those who were referred. Nearly all referred patients (102 [94.4\%]) died at the Queen Elizabeth II Health Sciences Centre, whereas a third (54 [32.5\%]) of potential donors who were not referred died at another institution. There were

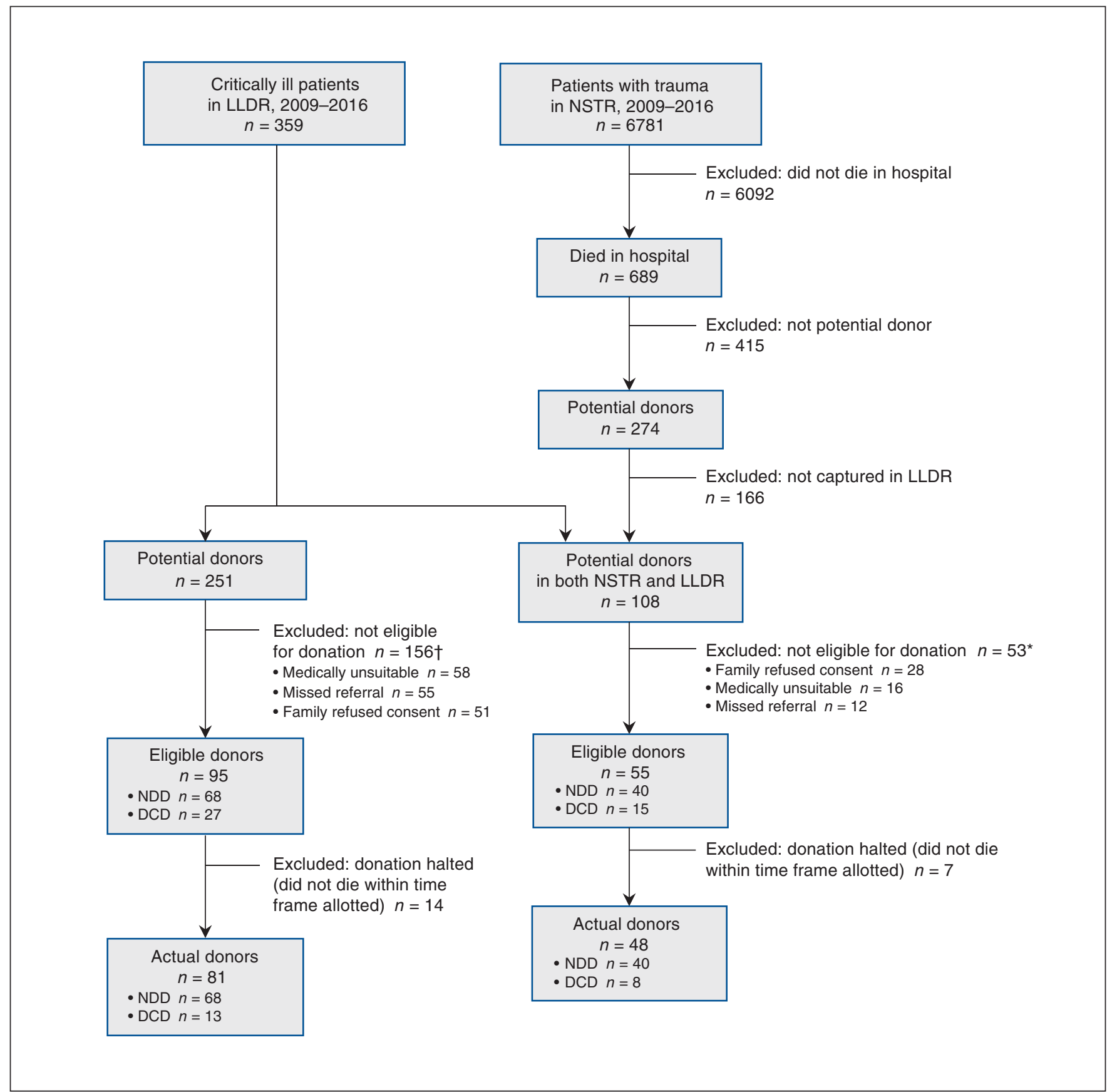

Figure 1: Flow diagram showing organ donation in Nova Scotia, 2009/10 to 2015/16. Cell sizes less than 5 have been suppressed. *Eight patients were ineligible for more than 1 reason; $\uparrow 3$ patients were ineligible for more than 1 reason. Note: $D C D=$ donation after circulatory death, LLDR = Legacy of Life Donor Registry, NDD = neurologic determination of death, NSTR = Nova Scotia Trauma Registry. 
differences in injury type, injury cause, ICECI codes, number of intermediate facilities, transport mode and trauma team activation between referred and nonreferred potential donors and between potential donors and patients who were not potential donors.
Overall, there were 359 potential donors (108 with trauma and 251 without trauma) in the Legacy of Life Donor Registry (Table 2). The consent rates were 68.7\% (57/83) and $65.5 \%$ (97/148), respectively. The conversion rate was $84 \%$ among both patients with trauma (48/57) and patients without

Table 1 (part 1 of 2): Characteristics of patients with trauma who died in hospital in Nova Scotia, 2009/10 to 2015/16

\begin{tabular}{|c|c|c|c|c|c|c|}
\hline \multirow[b]{2}{*}{ Characteristic } & \multicolumn{3}{|c|}{ Potential organ donors, no. $(\%)^{\star} \dagger$} & \multirow[b]{2}{*}{$p$ value $\ddagger$} & \multirow[b]{2}{*}{$\begin{array}{c}\text { Not potential } \\
\text { organ donors, } \\
\text { no. }(\%) \\
n=415\end{array}$} & \multirow[b]{2}{*}{$p$ value $\S$} \\
\hline & $\begin{array}{c}\text { Total } \\
n=274\end{array}$ & $\begin{array}{l}\text { Referred to } \\
\text { Legacy of Life } \\
\text { Program } \\
n=108\end{array}$ & $\begin{array}{c}\text { Not referred to } \\
\text { Legacy of Life } \\
\text { Program } \\
n=166\end{array}$ & & & \\
\hline Age, yr, mean \pm SD & $55.6 \pm 23.5$ & $44.7 \pm 20.5$ & $61.4 \pm 23.5$ & $<0.001$ & $71.9 \pm 20.9$ & $<0.001$ \\
\hline Male sex & $200(73.0)$ & $85(78.7)$ & $115(69.3)$ & 0.1 & $265(63.8)$ & 0.01 \\
\hline Residence & & & & 0.9 & & 0.4 \\
\hline Urban & $185(67.5)$ & $73(67.6)$ & $112(67.5)$ & & $290(69.9)$ & \\
\hline Rural & $85(31.0)$ & $33(30.6)$ & $52(31.3)$ & & $123(29.6)$ & \\
\hline Missing & $n<5$ & $n<5$ & $n<5$ & & $n<5$ & \\
\hline Injury location & & & & 0.8 & & 0.9 \\
\hline $\begin{array}{l}\text { Within Halifax Regional } \\
\text { Municipality }\end{array}$ & 95 (34.7) & $39(36.1)$ & $56(33.7)$ & & $150(36.1)$ & \\
\hline $\begin{array}{l}\text { Outside Halifax Regional } \\
\text { Municipality }\end{array}$ & $163(59.5)$ & $62(57.4)$ & $101(60.8)$ & & $241(58.1)$ & \\
\hline Missing & $16(5.8)$ & $7(6.5)$ & $9(5.4)$ & & $24(5.8)$ & \\
\hline No. of intermediate facilities & & & & 0.003 & & $<0.001$ \\
\hline 0 & $141(51.4)$ & $45(41.7)$ & $96(57.8)$ & & $283(68.2)$ & \\
\hline 1 & $117(42.7)$ & $56(51.8)$ & $61(36.7)$ & & $81(19.5)$ & \\
\hline$\geq 2$ & $16(5.8)$ & $7(6.5)$ & $9(5.4)$ & & $29(7.0)$ & \\
\hline Missing & $0(0)$ & $0(0)$ & $0(0)$ & & $22(5.3)$ & \\
\hline Injury type & & & & $<0.001$ & & $<0.001$ \\
\hline Blunt & $242(88.3)$ & $84(77.8)$ & $158(95.2)$ & & $334(80.5)$ & \\
\hline Drowning/asphyxia & $23(8.4)$ & $17(15.7)$ & $6(3.6)$ & & $21(5.1)$ & \\
\hline Other & $9(3.3)$ & $7(6.5)$ & $n<5$ & & $60(14.4)$ & \\
\hline Injury cause & & & & 0.002 & & $<0.001$ \\
\hline Fall & $116(42.3)$ & $35(32.4)$ & $81(48.8)$ & & $247(59.5)$ & \\
\hline Motor vehicle collision & $75(27.4)$ & $26(24.1)$ & $49(29.5)$ & & $50(12.0)$ & \\
\hline Self-harm & $30(10.9)$ & $18(16.7)$ & $12(7.2)$ & & $17(4.1)$ & \\
\hline Otherף & $53(19.3)$ & $29(26.8)$ & $24(14.4)$ & & $101(24.3)$ & \\
\hline ICD-10-CA injury code ${ }^{* *}$ & & & & 0.004 & & $<0.001$ \\
\hline $\begin{array}{l}\text { Traumatic subdural } \\
\text { hemorrhage }\end{array}$ & $192(70.1)$ & $74(68.5)$ & $118(71.1)$ & & $153(36.9)$ & \\
\hline $\begin{array}{l}\text { Traumatic subarachnoid } \\
\text { hemorrhage }\end{array}$ & $154(56.2)$ & $62(57.4)$ & $92(55.4)$ & & $85(20.5)$ & \\
\hline Focal brain injury & $117(42.7)$ & $54(50.0)$ & $63(38.0)$ & & $44(10.6)$ & \\
\hline Fracture, base of skull & $101(36.9)$ & $52(48.1)$ & $49(29.5)$ & & $20(4.8)$ & \\
\hline Fracture, vault of skull & $70(25.5)$ & $38(35.2)$ & 32 (19.3) & & $23(5.5)$ & \\
\hline Traumatic cerebral edema & $59(21.5)$ & $34(31.5)$ & $25(15.1)$ & & $14(3.4)$ & \\
\hline Diffuse brain injury & $52(19.0)$ & $28(25.9)$ & $24(14.4)$ & & $n<5$ & \\
\hline Other & $116(42.3)$ & $38(35.2)$ & $78(47.0)$ & & $89(21.4)$ & \\
\hline
\end{tabular}


Table 1 (part 2 of 2): Characteristics of patients with trauma who died in hospital in Nova Scotia, 2009/10 to 2015/16

\begin{tabular}{|c|c|c|c|c|c|c|}
\hline \multirow[b]{2}{*}{ Characteristic } & \multicolumn{3}{|c|}{ Potential organ donors, no. $(\%)^{\star} \dagger$} & \multirow[b]{2}{*}{$p$ value $\neq$} & \multirow[b]{2}{*}{$\begin{array}{c}\text { Not potential } \\
\text { organ donors, } \\
\text { no. }(\%) \\
n=415\end{array}$} & \multirow[b]{2}{*}{$p$ value $\S$} \\
\hline & $\begin{array}{c}\text { Total } \\
n=274\end{array}$ & $\begin{array}{l}\text { Referred to } \\
\text { Legacy of Life } \\
\text { Program } \\
n=108\end{array}$ & $\begin{array}{c}\text { Not referred to } \\
\text { Legacy of Life } \\
\text { Program } \\
n=166\end{array}$ & & & \\
\hline \multicolumn{4}{|l|}{ Comorbidities†† } & \multicolumn{2}{|l|}{0.001} & $<0.001$ \\
\hline Cardiac/vascular & $107(39.1)$ & $19(17.6)$ & $88(53 / 0)$ & \multicolumn{3}{|c|}{$257(61.9)$} \\
\hline Neurological & $51(18.6)$ & $21(19.4)$ & $30(18.1)$ & \multicolumn{3}{|c|}{$92(22.2)$} \\
\hline Renal & $21(7.7)$ & $0(0)$ & $21(12.6)$ & \multicolumn{3}{|c|}{$40(9.6)$} \\
\hline Infectious disease & $19(6.9)$ & $n<5$ & $n>5 \ddagger \ddagger$ & \multicolumn{3}{|c|}{$113(27.2)$} \\
\hline Respiratory & $18(6.6)$ & $n<5$ & $n>5$ 拉 & \multicolumn{3}{|c|}{$49(11.8)$} \\
\hline Neoplastic & $17(6.2)$ & $5(4.6)$ & $12(7.2)$ & \multicolumn{3}{|c|}{$68(16.4)$} \\
\hline Gastrointestinal & $9(3.3)$ & $n<5$ & $n>5$ 㧊 & \multicolumn{3}{|c|}{$39(9.4)$} \\
\hline Other & $125(45.6)$ & $39(36.1)$ & $86(51.8)$ & \multicolumn{3}{|c|}{$185(44.6)$} \\
\hline \multicolumn{7}{|l|}{ Injury severity } \\
\hline $\begin{array}{l}\text { Injury Severity Score, mean } \\
\pm \mathrm{SD}\end{array}$ & $28.5 \pm 12.1$ & $29.3 \pm 11.5$ & $27.7 \pm 12.5$ & 0.04 & $20.7 \pm 11.0$ & $<0.001$ \\
\hline $\begin{array}{l}\text { Abbreviated Injury Scale, } \\
\text { Head, mean } \pm \text { SD }\end{array}$ & $4.5 \pm 0.7$ & $4.8 \pm 0.5$ & $4.3 \pm 0.8$ & $<0.001$ & $3.9 \pm 1.3$ & $<0.001$ \\
\hline $\begin{array}{l}\text { Scene Glasgow Coma } \\
\text { Scale, mean } \pm \text { SD }\end{array}$ & $6.9 \pm 4.6$ & $5.1 \pm 3.5$ & $8.0 \pm 4.9$ & $<0.001$ & $11.0 \pm 4.9$ & $<0.001$ \\
\hline Trauma team activation & $113(41.2)$ & $59(54.6)$ & $\mathrm{p}(32.5)$ & $<0.001$ & $55(13.2)$ & $<0.001$ \\
\hline \multicolumn{4}{|l|}{ Transport to final institution } & \multicolumn{2}{|l|}{$<0.001$} & $<0.001$ \\
\hline Land & $194(70.8)$ & $60(55.6)$ & $134(80.7)$ & \multicolumn{3}{|c|}{$359(86.5)$} \\
\hline Air§§ & 53 (19.3) & $34(31.5)$ & $19(11.4)$ & \multicolumn{3}{|c|}{$13(3.1)$} \\
\hline Both land and air & $22(8.0)$ & $13(12.0)$ & $9(5.4)$ & \multicolumn{3}{|c|}{$12(2.9)$} \\
\hline Otherףी & $n<5$ & $n<5$ & $n<5$ & \multicolumn{3}{|c|}{$12(2.9)$} \\
\hline Missing & $n<5$ & $n<5$ & $n<5$ & \multicolumn{3}{|c|}{$19(4.6)$} \\
\hline \multicolumn{7}{|l|}{ Hospital stay } \\
\hline $\begin{array}{l}\text { Intensive care unit } \\
\text { admission }\end{array}$ & $183(66.8)$ & $85(78.7)$ & $98(59.0)$ & $<0.001$ & $76(18.3)$ & $<0.001$ \\
\hline $\begin{array}{l}\text { Intensive care unit length of } \\
\text { stay, } d \text {, mean } \pm S D\end{array}$ & $4.4 \pm 5.2$ & $3.1 \pm 3.0$ & $5.9 \pm 6.6$ & 0.001 & $4.7 \pm 7.3$ & 0.7 \\
\hline $\begin{array}{l}\text { Hospital length of stay, } d \text {, } \\
\text { mean } \pm \text { SD }\end{array}$ & $7.0 \pm 27.8$ & $3.1 \pm 3.1$ & $9.3 \pm 34.7$ & 0.004 & $9.3 \pm 21.1$ & 0.2 \\
\hline Ventilator days, mean \pm SD & $2.9 \pm 3.6$ & $3.0 \pm 3.0$ & $2.8 \pm 4.0$ & 0.001 & $3.4 \pm 5.2$ & 0.3 \\
\hline Institution where patient died & & & & $<0.001$ & & $<0.001$ \\
\hline $\begin{array}{l}\text { Queen Elizabeth II Health } \\
\text { Sciences Centre }\end{array}$ & $214(78.1)$ & $102(94.4)$ & $112(67.5)$ & & $211(50.8)$ & \\
\hline Other & $60(21.9)$ & $6(5.6)$ & $54(32.5)$ & & $204(49.2)$ & \\
\hline \multicolumn{7}{|c|}{ 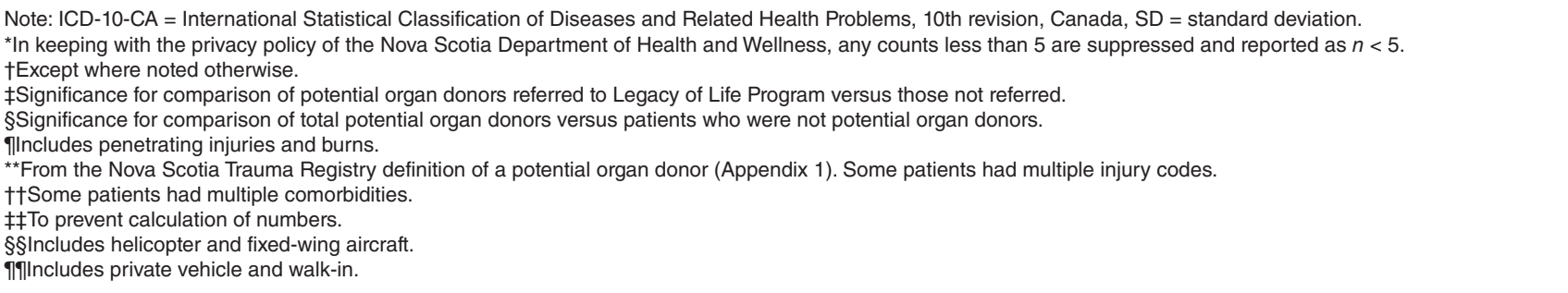 } \\
\hline
\end{tabular}


Table 2: Organ donation by patients with and without trauma

\begin{tabular}{|c|c|c|c|}
\hline \multirow[b]{2}{*}{ Variable } & \multicolumn{2}{|c|}{ No. $(\%)$ of patients* } & \multirow[b]{2}{*}{$p$ value } \\
\hline & $\begin{array}{c}\text { With trauma } \\
\quad n=48\end{array}$ & $\begin{array}{c}\text { Without } \\
\text { trauma } \\
n=81\end{array}$ & \\
\hline Conversion rate, \%† & 84 & 84 & 0.9 \\
\hline Consent rate‡ & 69 & 66 & 0.6 \\
\hline Age, yr, mean \pm SD & $39.7 \pm 20.5$ & $49.1 \pm 14.0$ & 0.002 \\
\hline Male sex & $34(71)$ & $38(47)$ & 0.01 \\
\hline \multicolumn{2}{|l|}{ Type of donor } & & 0.9 \\
\hline NDD & $40(83)$ & $68(84)$ & \\
\hline DCD & $8(17)$ & $13(16)$ & \\
\hline \multicolumn{3}{|c|}{ Medical Services Insurance card signed } & 0.8 \\
\hline Yes & $22(46)$ & $39(48)$ & \\
\hline No & $20(42)$ & $29(36)$ & \\
\hline Unknown & $6(12)$ & $13(16)$ & \\
\hline \multicolumn{3}{|c|}{ Medical Services Insurance donor classification§ } & 0.8 \\
\hline 1 & $18(38)$ & $31(38)$ & \\
\hline 2 & $5(10)$ & $8(10)$ & \\
\hline Missing & $25(52)$ & $42(52)$ & \\
\hline No. of organs donated & 203 & 335 & \\
\hline $\begin{array}{l}\text { No. of organs per } \\
\text { donor }\end{array}$ & 4.23 & 4.14 & \\
\hline \multicolumn{4}{|l|}{ Organ donated } \\
\hline Kidney & 91 & 153 & \\
\hline Liver & 37 & 58 & \\
\hline Lung & 32 & 71 & \\
\hline Pancreas & 23 & 32 & \\
\hline Heart & 20 & 21 & \\
\hline \multicolumn{4}{|c|}{$\begin{array}{l}\text { Note: } \mathrm{DCD} \text { = donation after circulatory death, NDD = neurologic determination } \\
\text { of death, } \mathrm{SD}=\text { standard deviation. } \\
\text { *Except where noted otherwise. } \\
\text { tProportion of eligible donors who became actual donors. } \\
\text { fProportion of eligible potential donors (or their families) approached for } \\
\text { consent who gave consent to become a donor. } \\
\text { §Donor } 1 \text { = patient indicated intent to donate all organs, donor } 2 \text { = patient } \\
\text { indicated consent to donate specific organs. }\end{array}$} \\
\hline
\end{tabular}

trauma (81/97). Donors with trauma were younger than those without trauma and were more likely to be male. Most donations followed neurologic determination of death (40 patients [83\%] with trauma and 68 patients [84\%] without trauma). Patients with trauma donated 203 organs (4.23 organs/donor) and those without trauma, 335 organs (4.14 organs/donor). The organ types procured most frequently were kidney and liver from patients with trauma, and kidney and lung from patients without trauma. The number of organs per donor was higher following neurologic determination of death (4.55) than after circulatory death (2.47).

The most common reasons for nondonation were family refusal of consent and medical unsuitability (Table 3). Families of potential donors with trauma refused consent more
Table 3: Reasons for nondonation among potential organ donors

\begin{tabular}{|c|c|c|c|}
\hline \multirow[b]{2}{*}{ Reasont } & \multicolumn{2}{|c|}{ No. (\%) of patients* } & \multirow[b]{2}{*}{$p$ value } \\
\hline & $\begin{array}{c}\text { With } \\
\text { trauma } \\
n=60\end{array}$ & $\begin{array}{l}\text { Without } \\
\text { trauma } \\
n=170\end{array}$ & \\
\hline Medically unsuitable & $16(26.7)$ & $58(34.1)$ & 0.4 \\
\hline Not declarable & $9(15.0)$ & $26(15.3)$ & 1.0 \\
\hline Age & $7(11.7)$ & $22(12.9)$ & 0.8 \\
\hline Other§ & $5(8.3)$ & $27(15.9)$ & 0.2 \\
\hline Unknown & $n<5$ & $7(4.1)$ & 0.8 \\
\hline $\begin{array}{l}\text { Did not die within time } \\
\text { frame allotted }\end{array}$ & $7(11.7)$ & $14(8.2)$ & 0.4 \\
\hline Family refused consent & $28(46.7)$ & $51(30.0)$ & 0.02 \\
\hline $\begin{array}{l}\text { Did not want to wait } \\
\text { any longer for organ } \\
\text { donation process to } \\
\text { occur }\end{array}$ & $11(18.3)$ & $8(4.7)$ & $<0.001$ \\
\hline Family belief & 8 (13.3) & $14(8.2)$ & 0.2 \\
\hline Unknown & $9(15.0)$ & $29(15.3)$ & 0.7 \\
\hline Missed referral & $12(20.0)$ & $55(32.4)$ & 0.1 \\
\hline Medically unsuitable & $6(10.0)$ & $29(17.1)$ & 0.2 \\
\hline $\begin{array}{l}\text { Family refused consent } \\
\text { or was not approached }\end{array}$ & $n<5$ & $0(0)$ & 0.1 \\
\hline Unknown & $5(8.3)$ & $26(15.3)$ & 0.2 \\
\hline \multicolumn{4}{|c|}{$\begin{array}{l}\text { *In keeping with the privacy policy of the Nova Scotia Department of Health and } \\
\text { Wellness, any counts less than } 5 \text { are suppressed and reported as } n<5 \text {. } \\
\text { †Some patients did not become organ donors for more than } 1 \text { reason. } \\
\text { †The age limit for donation after circulatory death was } 54 \text { years before June } 2010 \\
\text { and } 64 \text { years after June } 2010 \text {. } \\
\text { \$Includes cancer, multiorgan failure, hepatitis, sepsis and renal failure. } \\
\text { qTime frame was } 2 \text { hours following withdrawal of life support. }\end{array}$} \\
\hline
\end{tabular}

often than those of potential donors without trauma. Among the latter group, medical unsuitability and family refusal of consent were the most common reasons for nondonation. In addition, 21 patients (7 with trauma and 14 without) were eligible for donation after circulatory death but did not die within 2 hours following withdrawal of life support.

Of the 359 potential donors, 133 (37.0\%) had indicated their intent to donate by signing their health card. Of the 133, $61(45.9 \%)$ (22 with trauma and 39 without trauma) became donors. The remaining 72 patients did not donate because of medical unsuitability (40 [56\%]), missed referral (21 [29\%]) or family refusal of consent (14 [20\%]; in 3 cases, the patient was medically unsuitable and the family refused consent).

\section{Interpretation}

Of all trauma-related deaths in provincial hospitals, $40 \%$ met our broad definition of a potential donor, and 39\% of these potential donors were referred to the Legacy of Life Program. Potential donors who were not referred were older and less severely injured than referred patients. The conversion rate 
was $84 \%$ for both the trauma and nontrauma groups. Patients who had experienced trauma accounted for over one-third of organ donors in the province. Although the definition we used may have exaggerated the number of potential organ donors in the province, our findings still suggest that patients with trauma represent a significant pool of potential donors and that increased efforts should be considered to improve referrals and donations from this population.

Among patients with trauma who were referred for donation, family refusal of consent was the most common reason for failure to procure organs, which is consistent with reports from the United States, ${ }^{5,17}$ Mexico $^{18}$ and the Netherlands. ${ }^{6}$ Among potential donors who had not experienced trauma, medical unsuitability was the main reason for nondonation, followed by refusal of consent by the family. A total of $37 \%$ of all potential donors in the Legacy of Life Donor Registry had signed their health card indicating their intent to donate, yet most of these patients did not become donors. Most did not donate because of medical unsuitability or missed referral, but $20 \%$ ultimately failed to donate because their families refused consent. This is ethically problematic and constitutes a double standard in terms of the principle of substituted judgment (i.e., the surrogate's duty). ${ }^{19}$ Although the government of Nova Scotia passed the Human Organ and Tissue Donation Act in 2010 declaring that any capable person may consent in writing to donate specific organs or tissues and that such consent is binding, ${ }^{20}$ this act has not been proclaimed. There is evidence that families are more likely to consent if they have more contact with organ procurement organizations and discussions surrounding organ donation. ${ }^{21}$

Potential donors among the trauma population were more acutely ill than patients who were not potential donors and yet in many cases were not referred to the Legacy of Life Program. The necessary focus on patient resuscitation in hopes of a better outcome in the initial hours or days of care may in part explain this. In Nova Scotia, we are working to improve the organ donation system by developing a more focused plan with the transplantation group, establishing regionally based donation physicians (i.e., intensivists with an interest in donation) and implementing a data management system so missed opportunities can be recognized and information is fed back to professionals on the front line in a timely fashion. Legislating the mandatory referral of potential donors may also help to reduce the number of missed referrals. Canadian health officials credit an increase of $23 \%$ in donations over the past decade in part to mandatory referral for transplantation in some provinces. ${ }^{2}$ Although Nova Scotia does not have mandatory referral, there is "required request," which is an expectation that health care professionals are required to advise potential donors about organ donation. Having all provinces implement mandatory referral could further increase overall donation rates.

\section{Limitations}

Data were collected from a provincial population-based trauma registry and a provincial organ procurement organization; thus, our findings are susceptible to known limitations of retrospective data collection. Another limitation is the criteria used to identify potential donors in the Nova Scotia Trauma Registry, which we based on recommendations from the Canadian Blood Services Deceased Donor Data Working Group. ${ }^{16}$ Although the group recommended ventilation within 24 hours of death as a criterion, the Nova Scotia Trauma Registry captures only whether a patient required ventilation at any time during the hospital stay; thus, we likely overestimated the number of potential donors identified in the Nova Scotia Trauma Registry. Furthermore, information on why some potential donors $(n=166)$ were not referred for donation was unavailable. Since the criteria for referral to the Legacy of Life Program are different from eligibility criteria, it is unclear whether missed referrals were potential donors. Finally, our results may not be generalizable to other regions or institutions that differ in their definition of a patient with trauma, or their criteria and processes for organ donation.

\section{Conclusion}

Using a broad definition of a potential donor, we found that $40 \%$ of patients with trauma who died in Nova Scotia hospitals were potential donors, yet only $39 \%$ of these patients were referred to the Legacy of Life Program. Among potential donors who were referred, the most common reasons for nondonation were family refusal of consent and medical unsuitability. Further work is required to improve organ donation by those who experience trauma in Canada.

\section{References}

1. Grinyó JM. Why is organ transplantation clinically important? Cold Spring Harb Perspect Med 2013;3:a014985.

2. Organ donation and transplantation in Canada: system progress report 2006-2015. Ottawa: Canadian Blood Services; 2016. Available: https://blood.ca/sites/ default/files/ODT_Report.pdf (accessed 2017 July 24).

3. Deceased organ donor potential in Canada: report. Ottawa: Canadian Institute for Health Information; 2014. Available: https://www.cihi.ca/web/resource/en/ organdonorpotential_2014_en.pdf (accessed 2017 June 13).

4. Finger EB. Organ procurement considerations in trauma. Medscape (updated 2016 Jan. 4). Available: http://emedicine.medscape.com/article/434643 -overview (accessed 2017 June 9).

5. Kemp CD, Cotton BA, Johnson JC, et al. Donor conversion and organ yield in traumatic brain injury patients: missed opportunities and missed organs. 7 Trauma 2008;64:1573-80.

6. Kompanje EJO, Bakker J, Slieker FJA, et al. Organ donations and unused potential donations in traumatic brain injury, subarachnoid haemorrhage and intracerebral haemorrhage. Intensive Care Med 2006;32:217-22.

7. Faucher A, Savary D, Jund J, et al. Out-of-hospital traumatic cardiac arrest: an underrecognized source of organ donors. Transpl Int 2014;27:42-8.

8. Shafer TJ, Ehrle RN, Davis KD, et al. Increasing organ recovery from level I trauma centers: the in-house coordinator intervention. Prog Transplant 2004; 14:250-63.

9. Joseph B, Khalil M, Pandit V, et al. Increasing organ donation after cardiac death in trauma patients. Am 7 Surg 2015;210:468-72.

10. Call to action: a strategic plan to improve organ and tissue donation and transplantation performance for Canadians. Ottawa: Canadian Blood Services; 2011. Available: https://blood.ca/sites/default/files/otdt-indx-final-c2a.pdf (accessed 2017 July 5).

11. Badovinac K, Greig PD, Ross H, et al. Organ utilization among deceased donors in Canada, 1993-2002. Can 7 Anaesth 2006;53:838-44.

12. Kramer AH, Zygun DA, Doig CJ, et al. Incidence of neurologic death among patients with brain injury: a cohort study in a Canadian health region. CMAf 2013;185:E838-45.

13. Kramer AH, Baht R, Doig CJ. Time trends in organ donation after neurologic determination of death: a cohort study. CMAJ Open 2017;5:E19-27.

14. Trauma stops here: annual report 2016. Halifax: Trauma Nova Scotia. Available: http://docs.wixstatic.com/ugd/bb84cc_c1c981a1452445c2ba6708030fdedf40. pdf (accessed 2017 Aug. 4).

15. Organ and tissue donation process: what health professionals need to know. Halifax: Nova Scotia Department of Health and Wellness; Legacy of Life: Nova 
Scotia Organ and Tissue Donation Program; 2009 (updated March 2015). Available: www.legacyoflife.ns.ca/health_professionals/Organ-and-Tissue -Donation-Process-What-Health-Professionals-Need-to-Know.pdf (accessed 2017 June 11).

16. Deceased Donation Data Working Group. Ottawa: Canadian Blood Services; 2016. Available: https://professionaleducation.blood.ca/sites/msi/files/ DDDWG_report_FINAL\%202016-06-30.pdf (accessed 2017 June 11).

17. Raoof M, Joseph BA, Friese RS, et al. Organ donation after traumatic cardiopulmonary arrest. Am 7 Surg 2011;202:701-5, discussion 705-6.

18. Guerra-Sáenz EK, Narváez-Navarro AG, Hernández-López AC, et al. Causes for an incomplete donation process at a tertiary care hospital. Transplant Proc 2016;48:552-5

19. Bramstedt KA. Family refusals of registered consents: the disruption of organ donation by double-standard surrogate decision-making. Intern Med f 2013;43: 120-3.

20. Nova Scotia Legislature. Human Organ and Tissue Donation Act, 2010, Bill 121 (as passed), 1st reading, Nov. 30, 2010 (link to Bill as introduced), 2nd reading, Dec. 9, 2010, 3rd reading, Dec. 10, 2010 (61st General Assembly, 2nd session). Available: https://nslegislature.ca/legc/bills/61st_2nd/3rd_read/b121.htm (accessed 2017 Aug. 12).

21. Siminoff LA, Gordon N, Hewlett J, et al. Factors influencing families' consent for donation of solid organs for transplantation. FAMA 2001;286:71-7.

Affiliations: Dalhousie University Medical School (Lanteigne, Hetherington, Cameron); Trauma Nova Scotia (Erdogan, Green), Nova Scotia Department of Health and Wellness; Department of Critical Care (Beed, Green), Dalhousie University, Halifax, NS

Contributors: Mete Erdogan, Stephen Beed and Robert Green conceived the study and contributed to the study design. Mete Erdogan was responsible for data collection (along with members of the Legacy of Life
Program and Trauma Nova Scotia) and data analysis. All of the authors contributed to data interpretation and drafting the manuscript and critically revising it for important intellectual content, gave final approval of the version to be published and agreed to be accountable for all aspects of the work.

Funding: This study was funded by the Trustees of the Ross Stewart Smith Studentship Fund through the Dalhousie University Faculty of Medicine's Research in Medicine program and by a Clinician Scientist Award from the Faculty of Medicine, Dalhousie University, Halifax, Nova Scotia.

Acknowledgements: The authors thank the Legacy of Life Program for support with the study design and data collection from the Legacy of Life Donor Registry (Janet Gallant, Cynthia Isenor, Tami Murphy, Jane Franklin, Mark A. Bonin, Lisa Gillis Rochon, Catherine MacPhee). They acknowledge Beth Sealy, coordinator, Nova Scotia Trauma Registry for assisting with data collection. They also thank the trustees of the Ross Stewart Smith Studentship Fund for providing funding through Dalhousie University's Research in Medicine program.

Disclaimer: Data used in this research were made available by Trauma Nova Scotia at the Nova Scotia Department of Health and Wellness. Any opinions expressed by the authors do not necessarily reflect the opinion of the Nova Scotia Department of Health and Wellness or Trauma Nova Scotia.

Supplemental information: For reviewer comments and the original submission of this manuscript, please see www.cmajopen.ca/content/6/3/ E300/suppl/DC1. 